\title{
ANALISIS DAN PERANCANGAN SISTEM INFORMASI RAWAT JALAN PADA KLINIK ST DI BANDUNG
}

\author{
Rini Astuti ${ }^{1}$ \\ Kevin Kristianto ${ }^{2}$ \\ Sekolah Tinggi Manajemen Informatika dan Komputer LIKMI \\ Jl. Ir. H. Juanda 96 Bandung 40132 \\ Email : riniastuti@likmi.ac.id ${ }^{1}$ \\ kevinkristansa@gmail.com²
}

\begin{abstract}
ABSTRAK
Sistem Informasi Rawat Jalan ini bertujuan untuk mendukung kegiatan operasional klinik yang mencakup layanan rawat jalan serta pengelolaan persediaan barang agar lebih cepat dan efisien. Untuk mendokumentasikan sistem ini menggunakan pendekatan berorientasi objek. Pada tahap pemodelan analisis, dibuat system use case, use case scenario, dan activity diagram. Pada tahap perancangan, pendekatan ini menggunakan class diagram dan sequence diagram. Sedangkan pada tahap implementasi, pendekatan ini menggunakan component diagram dan deployment diagram.

Dalam tahap pembangunan sistem informasi, penulis menggunakan bahasa pemrograman Java dengan Netbeans 7.2.1 sebagai development tool, serta MySQL sebagai database engine. Hasil dari pengerjaan ini berupa sistem informasi yang mampu menangani proses pendaftaran pasien, pemeriskaan pasien, pembayaran resep, pembelian produk, serta pembayaran utang terhadap pemasok. Sistem informasi yang dihasilkan mampu mempercepat waktu pemrosesan informasi pada setiap tahap dalam kegiatan operasional klinik..
\end{abstract}

Kata kunci : pemodelan, sistem informasi, metode berorientasi objek

\section{PENDAHULUAN}

Sebagai sarana kesehatan yang dekat dengan masyarakat, pengelola klinik-klinik kesehatan swasta perlu terus meningkatkan mutu tenaga pengelola klinik, kualitas pelayanan, serta persediaan barang. Untuk melaksanakan hal tersebut, diperlukan suatu sistem informasi yang mampu menangani serta mengurangi masalah-masalah yang timbul dalam ruang lingkup klinik. Pengelolaan data rekam medis pasien serta pengadaan barang menjadi kunci utama dalam memberkan pelayanan yang baik terhadap masyarakat. Klinik ST merupakan klinik kesehatan yang menyediakan jasa rawat jalan. Klinik tersebut belum memiliki suatu perangkat pengelolaan data, terutama dalam hal pencatatan rekam medis pasien, pengadaan barang, serta pembuatan laporan. Sistem informasi yang handal sangat diperlukan untuk menunjang kegiatan operasional serta meningkatkan kualitas pelayanan.

Sehingga untuk mengelola data dan informasi yang berhibungan dengan pelayanan administrasi pondok secara efisien dan efektif dibutuhkan suatu sistem informasi berbasis komputer yang merupakan salah satu bagian penting dalam memberikan pelayanan yang cepat, efektif, dan efisien guna membantu mengatasi permasalahan yang mungkin terjadi saat ini dan di masa yang akan datang. Pemodelan sistem informasi yang dibuat di penelitian ini diharapkan dapat membantu untuk meningkatkan pelayanan kepada pasien dan mendukung pengambilan keputusan pihak manajemen. 


\subsection{RUANG LIGKUP}

Ruang lingkup permasalahan terkait pemodelan analisis dan perancangan pada penelitian ini adalah sebagai berikut :

a. Proses pendaftaran dan pemanggilan pasien

b. Pencatatan identitas pasien

c. Proses pencatatan data pemeriksaan pasien

d. Pengelolaan data rekam medis pasien

e. Penerimaan biaya berobat dari pasien

f. Pencatatan data produk

g. Proses transaksi pembelian produk secara kredit

h. Pembayaran utang atas transaksi pembelian secara kredit terhadap supplier

i. Pembuatan daftar persediaan produk

j. Pembuatan laporan pendaftaran pasien, pengeluaran obat, pembelian, dan pembayaran utang.

\subsection{TUJUAN PENELITIAN}

Adapun tujuan dari penelitian dan pengembangan sistem di Pondok Wisata ini adalah sebagai berikut :

a. Data-data penting yang tersimpan dalam sistem selalu terjamin keamanannya dan terintegrasi satu sama lain

b. Menghindari duplikasi data yang berpotensi menyebabkan pemborosan dan kekeliruan

c. Sistem dapat menyediakan informasi mengenai persediaan barang secara akurat dan up-to-date

d. Mempercepat proses pembuatan laporan dengan format yang seragam

e. Membantu pihak pengelola untuk mengambil keputusan yang tepat dalam hal pengadaan barang.

\section{LANDASAN TEORI}

Secara umum model menggunakan gambar untuk mewakili realitas atau visi Model adalah representasi dari objek secara real. Pemodelan merupakan pendekatan pemecahan masalah yang menekankan gambar pada model sistem untuk mendokumentasikan dan memvalidasi sistem yang berjalan atau sistem yang diusulkan[8].

Pemodelan secara umum, dimengerti sebagai proses merepresentasikan objek nyata atau realita sebagai seperangkat persamaan matematika, grafis ataupun bagan agar mudah dipahami oleh pihak yang berkepentingan. Pemodelan dalam pengembangan sistem informasi, berevolusi selaras dengan pendekatan pengembangan sistem yang dilakukan. Proses analisis dan perancangan di sini dikerjakan melalui pemodelan.

\subsection{KONSEP DASAR PENDEKATAN BERORIENTASI OBJEK}

Pendekatan berorientasi objek merupakan suatu teknik atau cara pendekatan dalam melihat permasalahan dan sistem (sistem perangkat lunak. sistem informasi, atau sistem lainnva). Pendekatan berorientasi objek akan memandang sistem yang akan dikembangkan sebagai suatu kumpulan objek yang berkorespondensi dengan objekobjek dunia nvata. Ada banvak cara untuk mengabstraksikan dan memodelkan objekobjek tersebut, mulai dan abstraksi objek, kelas, hubungan antar kelas sampai abstraksi 
sistem. Saat mengabstraksikan dan memodelkan objek mi, data dan proses-proses yang dipunyai oleh objek akan dienkapsulasi (dibungkus) menjadi satu kesatuan.

Dalam pengembangan sistem informasi, konsep pendekatan berorientasi objek dapat diterapkan pada tahap analisis, perancangan, pemrograman, dan pengujian sistem. Ada berbagai teknik yang dapat digunakan pada masing-masing tahap tersebut, dengan aturan dan alat bantu pemodelan tertentu.

Sistem berorientasi objek merupakan sebuah sistem yang dibangun dengan berdasarkan metode berorientasi objek adalah sebuah sistem yang komponennva dibungkus (dienkapsulasi) menjadi kelompok data dan fungsi. Setiap komponen dalam sistem tersebut dapat mewarisi atribut dan sifat dan komponen lainnya. dan dapat berinteraksi satu sama lain.

Menurut Booch [1], karakteristik atau sifat-sifat yang dipunyai sebuah sistem berorientasi objek adalah sebagai berikut:

a. Abstraksi

prinsip untuk merepresentasikan dunia nyata yang kompleks menjadi satu bentuk model yang sederhana dengan mengabaikan aspek-aspek lain yang tidak sesuai dengan permasalahan

b. Enkapsulasi

pembungkusan atribut data dan layanan (operasi-operasi) yang dipunyai objek. untuk menyembunyikan implementasi dan objek sehingga objek lain tidak mengetahui cara kerja-nya.

c. Pewarisan (inheritance)

mekanisme yang memungkinkan satu objek mewarisi sebagian atau seluruh definisi dan objek lain sebagai bagian dan dirinya

d. Reusabilily

pemanfaatan kembali objek yang sudah didefinisikan untuk suatu permasalahan pada permasalahan lainnya yang melibatkan objek tersebut

e. Generalisasi dan Spesialisasi

menunjukkan hubungan antara kelas dan objek yang umum dengan kelas dan objek yang khusus

f. Komunikasi Antar Objek

komunikasi antar objek dilakukan lewat pesan (message) yang dikirim dan satu objek ke objek lainnya

g. Polymorphism

kemampuan suatu objek untuk digunakan di banyak tujuan yang berbeda dengan nama yang sama sehingga menghemat baris program.

\subsection{UNIFIED MODELING LANGUAGE (UML)}

Definisi Unified Modeling Language (UML) menurut Munawar [4] dalam buku "Pemodelan Visual dengan UML", yaitu : "Unified Modeling Language (UML) adalah salah satu alat bantu yang sangat handal dalam perkembangan sistem berorientasi objek.” (Munawar, 2005:17)

Definisi UML dalam buku "Software Engineering : A Practitioner's Approach", yaitu : "The Unified Modeling Language (UML) is a standard language for writing software blueprints. UML may be used to visualize, specify, construct, and document the artifacts of a software-intensive system." (Pressman, 2010:841) [6].

Pernyataan diatas menjelaskan bahwa UML adalah sebuah bahasa pemrograman standar yang digunakan untuk pembuatan perangkat lunak. UML dapat digunakan 
untuk memvisualisasikan, menentukan, membangun, dan mendokumentasikan sistem awal dari suatu perangkat lunak secara intensif.

Berdasarkan definisi para ahli tersebut dapat disimpulkan bahwa UML adalah sebuah bahasa pemrograman yang digunakan untuk merencanakan perancangan perangkat lunak. Jenis diagram yang digunakan di sini adalah use case diagram dan class diagram.

\section{METODOLOGI DAN PEMBAHASAN}

\subsection{METODOLOGI}

Metode yang akan dipakai di sini adalah merupakan pendekatan berorientasi objek untuk analisis sistem, dengan alat bantu diagram UML use case diagram dan class diagram. Analisis sistem (system analysis) dapat didefinisikan sebagai penguraian dari suatu proses informasi yang utuh ke dalam bagian-bagian komponennya dengan maksud untuk mengidentifikasikan dan mengevaluasi setiap permasalahan, kesempatan, hambatan yang terjadi dan kebutuhan-kebutuhan yang diharapkan sehingga dapat diusulkan perbaikan-perbaikan.

Di dalam tahap analisis sistem terdapat 4 tahap yang umum dilakukan pada saat menganalisis sistem, yaitu :

a. Survey

Tahap ini menjadi penting peranannya jika sistem yang dikembangkan akan digunakan sebagai pengganti sistem lama.

b. Analisis Sistem

Tahap ini meliputi pengumpulan data mengenai kebutuhan para user dan tujuan yang ingin dicapai jika system baru sudah berjalan.

c. System Requirement

Pada tahap ini ditentukan syarat-syarat yang harus dipenuhi agar sistem baru dapat berjalan umumnya ditentukan berdasarkan input yang dibutuhkan dan output yang dikehendaki.

d. Pelaporan hasil analisis

Laporan hasil analisis sebaiknya berisi pemodelan use case diagram dan spesifikasi-spesifikasi yang diinginkan oleh para user dan perancangan sistem secara global.

\subsection{PENGEMBANGAN DENGAN MODEL PROTOTYPING}

Menurut (Pressman, 2012:50), dalam melakukan perancangan sistem yang akan dikembangkan dapat menggunakan metode prototyping. Metode ini cocok digunakan untuk mengembangkan suatu perangkat lunak yang akan dikembangkan kembali. Metode ini dimulai dengan pengumpulan kebutuhan pengguna dilanjutkan dengan membuat suatu rancangan kilat yang selanjutnya kan dievaluasi kembali sebelum diproduksi secara benar. Prototype bukanlah sesuatu yang lengkap, melainkan sesuatu yang harus dievaluasi dan dimodifikasi kembali. Segala perubahan dapat terjadi pada saat prototype dibuat untuk memenuhi kebutuhan pengguna dan pada saat yang sama memungkinkan pengembang untuk lebih memahami kebutuhan pengguna secara lebih baik. Berikut adalah tahapan dalam metode prototyping :

a. Komunikasi dan pengumpulan data awal, yaitu analisis terhadap kebutuhan pengguna

b. Quick design (desain cepat), yaitu pembuatan desain secara umum untuk selenjutnya dikembangkan kembali.

c. Pembentukan prototype, yaitu pembuatan prototype termasuk pengujian dan penyempurnaan 
d. Evaluasi terhadap prototype, yaitu mengevaluasi prototype dan memperhalus analisis terhadap kebutuhan pengguna

e. Perbaikan prototype, yaitu pembuatan tipe yang sebenarnya berdasarkan hasil dari evaluasi prototype

f. Produksi akhir, yaitu memproduksi perangkat lunak secara benar sehingga dapat digunakan oleh pengguna.

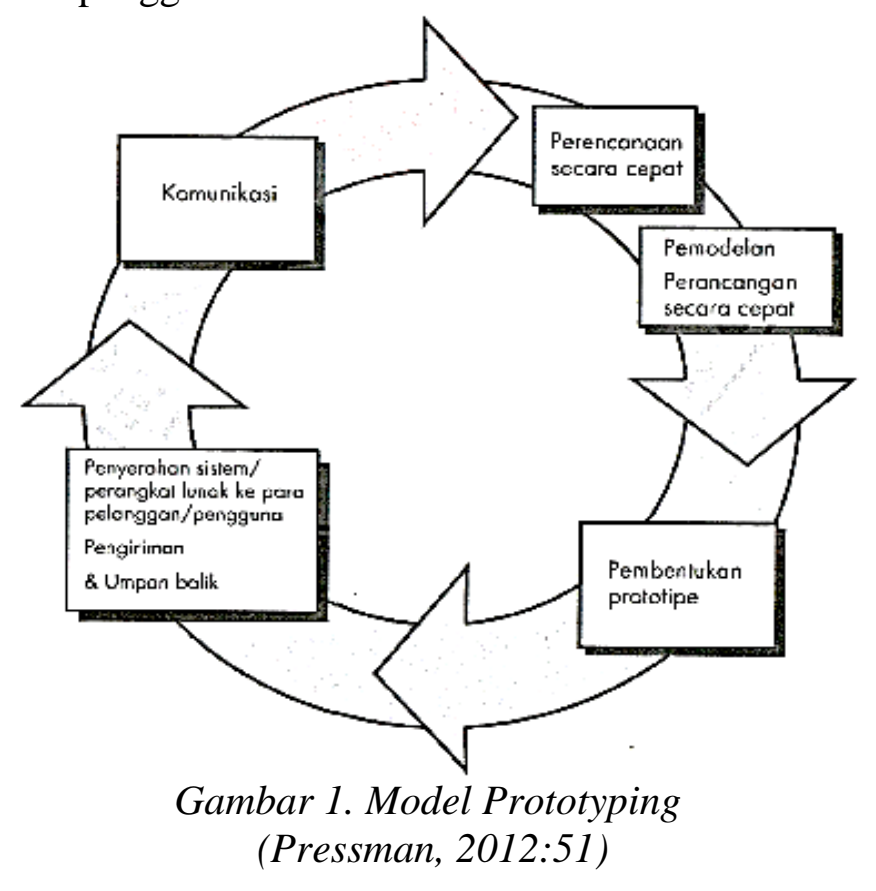

\subsection{PEMBAHASAN}

Proses bisnis sistem eawat jalan dijelaskan berdasarkan sistem dan prosedur yang dilengkapi dengan bagian-bagian terkait disertai dokumen yang digunakan oleh Klinik ST.

a. Prosedur pendaftaran pasien, memiliki tahapan sebagai berikut :

- Setiap pasien yang hendak berobat harus terlebih dahulu datang ke bagian pendaftaran

- Jika pasien baru pertama kali berobat, bagian pendaftaran akan mencatat identitas pasien pada buku identitas pasien dan kartu pemeriksaan

- Bagian pendaftaran akan mencatat nama pasien pada buku antrian

- Bagian pendaftaran akan memberikan nomor antrian kepada pasien

- Bagian pendaftaran akan memanggil nama pasien untuk masuk ke ruangan dokter sesuai dengan nomor antrian.

b. Prosedur pemeriksaan pasien

- Bagian pendaftaran menyerahkan kartu pemeriksaan pasien kepada perawat

- Dokter mendengarkan keluhan kesehatan yang diungkapkan pasien

- Dokter melakukan pemeriksaan fisik terhadap pasien

- Dokter mengidentifikasi penyakit yang diidap pasien

- Dokter melakukan tindakan pemberian jasa jika diperlukan

- Pasien membayar biaya konsultasi berikut tindakan pemberian jasa

- Dokter membuat resep (jika ada), kemudian memberikannya kepada pasien

- Perawat menulis hasil pemeriksaan pada kartu pemeriksaan pasien

c. Prosedur penebusan resep 
- Jika pasien hendak menebus resep di klinik, pasien menyerahkan kertas resep kepada asisten apoteker

- Asisten apoteker menyerahkan resep kepada apoteker

- Apoteker mengambilkan obat serta menuliskan aturan pemakaian pada kemasan obat dan menyerahkannya kepada asisten apoteker

- Asisten apoteker menghitung jumlah biaya obat yang harus dibayar

- Pasien menyerahkan sejumlah uang untuk membayar biaya obat

- Asisten apoteker menyerahkan obat kepada pasien sekaligus memberitahukan aturan pakai yang dituliskan apoteker pada kemasan obat

d. Prosedur pembelian produk

- Pemasok memberikan daftar produk kepada dokter. Daftar tersebut kemudian diberikan kepada apoteker untuk disimpan.

- Pada saat stok produk tinggal sedikit, apoteker akan membuat daftar pembelian produk yang akan diserahkan kepada dokter

- Dokter akan memeriksa daftar pembelian yang dibuat apoteker. Apabila daftar pembelian tidak disetujui baik karena jumlahnya terlalu banyak atau merk produk yang tidak sesuai, dokter akan memberitahu apoteker untuk merevisi daftar pembelian. Apabila daftar pembelian disetujui, apoteker memberikan daftar pembelian kepada bagian administrasi yang akan melakukan pemesanan kepada pemasok melalui telepon

- Produk yang dibeli akan diserahkan pemasok kepada apoteker pada siang atau sore hari di hari yang sama

- Pemasok juga akan memberikan faktur yang berisi total tagihan beserta tanggal jatuh tempo kepada bagian administrasi.

e. Prosedur pembayaran utang

- Bagian administrasi akan membuat daftar rencana pembayaran utang dan menyerahkannya kepada dokter. Jika dokter tidak menyetujui rencana pembayaran yang diajukan baik karena jumlahnya yang terlalu besar atau tanggal jatuh tempo dinilai masih lama, dokter akan memberitahukan bagian administrasi untuk melakukan revisi. Jika disetujui, dokter akan meminta bagian administrasi untuk menghubungi pemasok guna melakukan pembayaran

- Ketika pemasok datang, bagian administrasi akan melakukan pembayaran utang sesuai dengan rencana pembayaran yang disetujui dokter

- Pemasok memberikan bukti pembayaran utang kepada bagian administrasi.

Gambaran use case bisnis digambarkan seperti pada Gambar 2. 


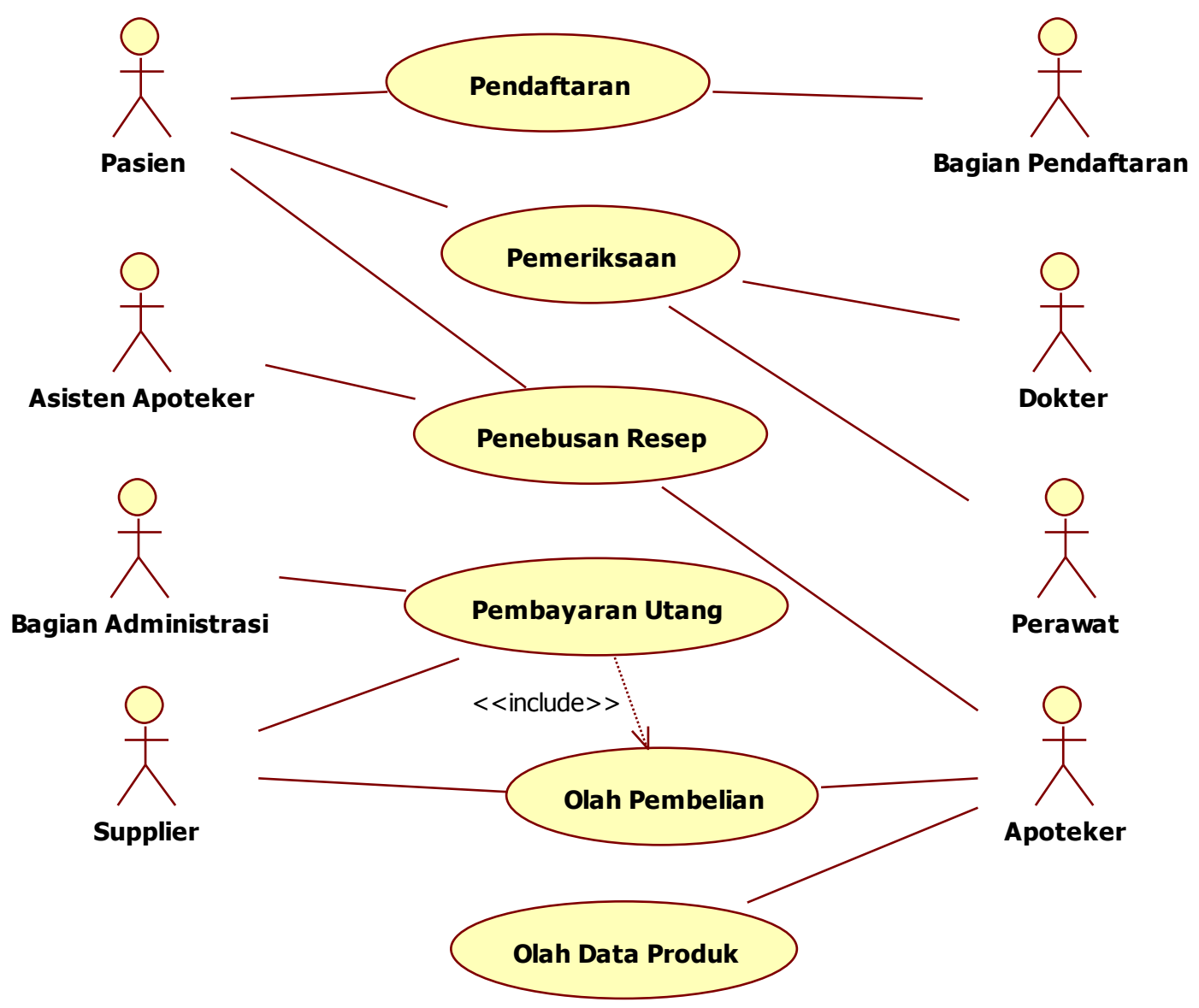

Gambar 2. Use Case Bisnis

\subsection{EVALUASI SISTEM}

Berdasarkan pengamatan yang penulis lakukan terhadap sistem yang berjalan, terdapat beberapa permasalahan sistem yang terjadi sebagai berikut :

a. Dokumen-dokumen penting masih dicatat pada kertas. Isi dokumen terkadang sulit untuk dibaca karena tinta yang pudar dan atau tulisan yang tidak jelas. Di samping itu, dokumen-dokumen tersebut seringkali tercecer ataupun hilang karena disimpan sembarangan.

b. Klinik menerapkan sistem manajemen yang terpusat sehingga kegiatan-kegiatan operasional klinik seperti pembelian obat serta pembayaran utang kepada pemasok harus berdasarkan pengesahan dan keputusan dokter. Di satu sisi hal ini dirasa baik karena dokter dapat mengontrol semua aktivitas pembuatan keputusan, di sisi lain pengambilan keputusan-keputusan operasional yang mendesak akan terhambat dan memakan waktu yang cukup lama.

c. Pendaftaran pasien memakan waktu yang lama karena bagian pendaftaran harus mencari kartu pemeriksaan pasien pada lemari penyimpanan terlebih dahulu, belum lagi jika kartu pemeriksaan pasien tidak ditemukan.

d. Redundansi kartu pemeriksaan pasien seringkali terjadi karena beberapa hal, yakni kartu pemeriksaan lama sudah terisi penuh ataupun tidak ditemukan.

e. Manajemen pengawasan hanya dilakukan oleh dokter selaku pemilik klinik, sehingga dokter memiliki tugas sampingan yang banyak.

f. Seringkali daftar persediaan obat yang dibuat tidak sesuai dengan data pada buku produk masuk dan buku obat keluar. Hal ini mungkin terjadi karena apoteker lupa menuliskan data obat yang telah dijual kepada pasien pada buku obat keluar. 
g. Apoteker dan asisten apoteker tidak terawasi dengan baik. Dimungkinkan terjadi manipulasi harga obat pada saat pasien memberikan resep dan melakukan pembayaran.

h. Dokter juga tidak dapat memantau stok produk yang tersedia secara real time.

\subsection{ANALISIS SISTEM}

Analisis Sistem merupakan kegiatan pengumpulan data dan mengidentifikasi kebutuhan sistem meliputi kebutuhan informasi, dan kebutuhan program aplikasi.

\subsubsection{KEBUTUHAN INFORMASI}

Informasi yang dibutuhkan dalam sistem rawat jalan di sini disusun pada Tabel 1 . Tabel 1. Tabel Kebutuhan Informasi

\begin{tabular}{|c|l|l|l|}
\hline No & \multicolumn{1}{|c|}{$\begin{array}{c}\text { Informasi yang } \\
\text { dibutuhkan }\end{array}$} & \multicolumn{1}{|c|}{ Tujuan } & \multicolumn{1}{|c|}{ Frekuensi } \\
\hline 1 & Data pasien & $\begin{array}{l}\text { Bagian } \\
\text { Pendaftaran }\end{array}$ & $\begin{array}{l}\text { Saat pasien pertama kali berobat di } \\
\text { klinik }\end{array}$ \\
\hline 2 & Data pendaftaran pasien & $\begin{array}{l}\text { Bagian } \\
\text { pendaftaran }\end{array}$ & $\begin{array}{l}\text { Setiap klinik melakukan kegiatan } \\
\text { praktek }\end{array}$ \\
\hline 3 & Data pemeriksaan & Perawat & Setiap pasien selesai diperiksa \\
\hline 4 & Data resep & $\begin{array}{l}\text { Pasien, Asisten } \\
\text { Apoteker, } \\
\text { Apoteker }\end{array}$ & $\begin{array}{l}\text { Setiap kali pasien menebus resep } \\
\text { di klinik }\end{array}$ \\
\hline 5 & Data pemasok & $\begin{array}{l}\text { Dokter, } \\
\text { Apoteker }\end{array}$ & $\begin{array}{l}\text { Saat pertama kali pemasok } \\
\text { memberikan daftar obat }\end{array}$ \\
\hline 6 & Data obat & $\begin{array}{l}\text { Dokter, } \\
\text { Apoteker }\end{array}$ & $\begin{array}{l}\text { Saat mendapatkan daftar obat dari } \\
\text { pemasok }\end{array}$ \\
\hline 7 & Faktur pembelian produk & $\begin{array}{l}\text { Bagian } \\
\text { Administrasi }\end{array}$ & $\begin{array}{l}\text { Setiap kali pemasok mengirimkan } \\
\text { produk }\end{array}$ \\
\hline 8 & Bukti pembayaran utang & $\begin{array}{l}\text { Bagian } \\
\text { Administrasi }\end{array}$ & $\begin{array}{l}\text { Setiap kali melakukan pembayaran } \\
\text { utang kepada pemasok }\end{array}$ \\
\hline 9 & $\begin{array}{l}\text { Bukti pembayaran biaya } \\
\text { berobat }\end{array}$ & Pasien & $\begin{array}{l}\text { Setiap kali pasien telah melakukan } \\
\text { pembayaran }\end{array}$ \\
\hline 10 & Daftar utang & Dokter & Setiap bulan \\
\hline 11 & Daftar persediaan obat & Dokter & Setiap bulan \\
\hline 12 & Laporan pendaftaran & Dokter & Setiap bulan \\
\hline 13 & Laporan pembelian & Dokter & Setiap bulan \\
\hline 14 & Laporan pembayaran utang & Dokter & Setiap bulan \\
\hline 15 & Laporan pengeluaran obat & Dokter & Setiap bulan \\
\hline & & & \\
\hline
\end{tabular}

\subsubsection{KEBUTUHAN PROGRAM APLIKASI}

Program aplikasi yang dibutuhkan dalam sistem informasi ini dengan sistem baru diuraikan pada Tabel 2.

Tabel 2. Tabel Kebutuhan Program Aplikasi

\begin{tabular}{|c|l|l|}
\hline No & \multicolumn{1}{|c|}{ Deskripsi Kebutuhan } & \multicolumn{1}{c|}{ Keterangan } \\
\hline 1 & Mengelola data pasien & Tambah, ubah, hapus, cari, simpan \\
\hline 2 & Mengelola data pemasok & Tambah, ubah, hapus, cari, simpan \\
\hline 3 & Mengelola data produk & $\begin{array}{l}\text { Tambah, ubah, hapus, cari, simpan, } \\
\text { cetak }\end{array}$ \\
\hline 4 & Mengelola data pendaftaran & Tambah, ubah, cari, simpan \\
\hline
\end{tabular}




\begin{tabular}{|c|l|l|}
\hline No & \multicolumn{1}{|c|}{ Deskripsi Kebutuhan } & \multicolumn{1}{c|}{ Keterangan } \\
\hline 5 & Mengelola data pemeriksaan & Tambah, cari, simpan \\
\hline 6 & Mengelola data pembelian & Tambah, cari, simpan \\
\hline 7 & Mengelola data utang & Tampilkan, filter, cari, cetak \\
\hline 8 & Mengelola data pembayaran utang & Tambah, cari, simpan \\
\hline 9 & Mengelola laporan pendaftaran & Tampilkan, cetak \\
\hline 10 & Mengelola laporan pengeluaran obat & Tampilkan, cetak \\
\hline 11 & Mengelola laporan pembelian & Tampilkan, cetak \\
\hline 10 & Mengelola laporan pembayaran utang & Tampilkan, cetak \\
\hline
\end{tabular}

\subsubsection{PEMODELAN FUNGSIONAL}

Pemodelan fungsional yang dibuat menggunakan diagram use case sistem. Use case sistem yang ada dalam sistem informasi rawat jalan di Klinik ST memiliki aktor yang terlibat langsung dalam sistem tersebut yaitu Bagian Pendaftaran, Dokter, Bagian Administrasi dan Apoteker. System use case ditampilkan pada Gambar 3.

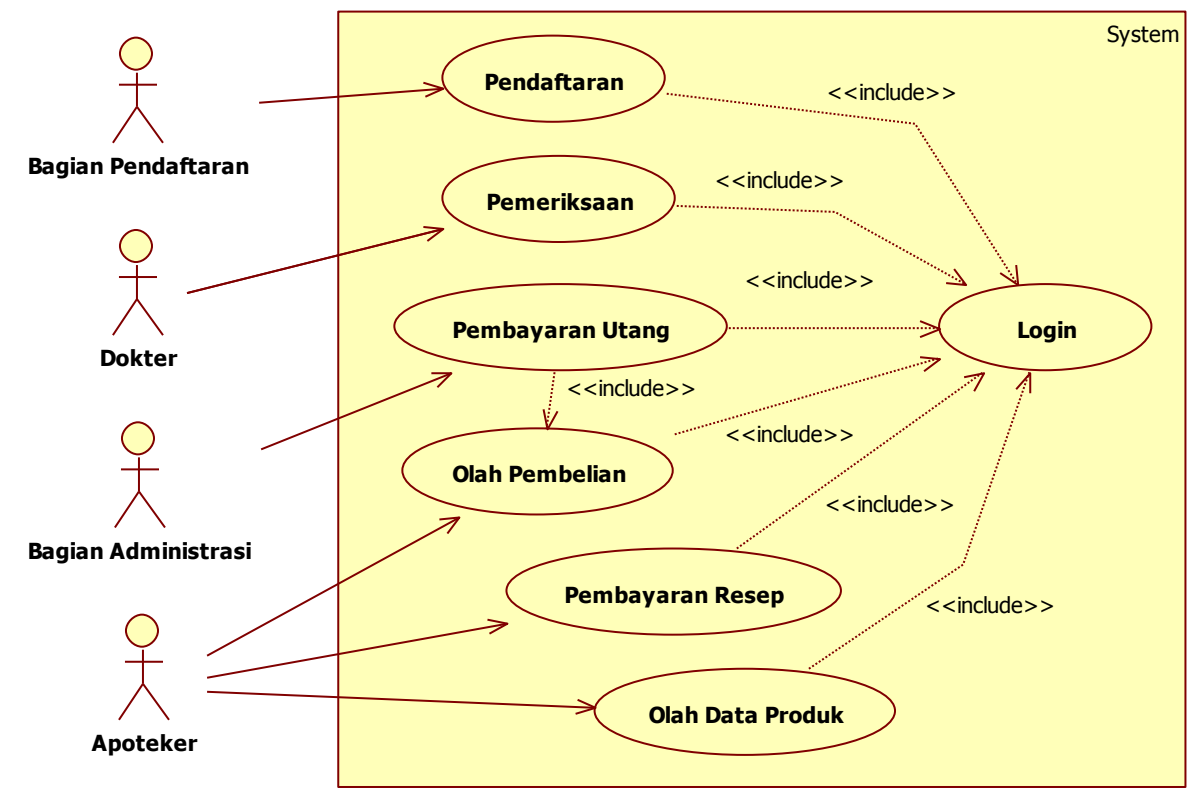

Gambar 3. Diagram Use Case Sistem

Dalam use case sistem ini fungsi yang diperlukan adalah pendaftaran, pemeriksaan untuk mencatat hasil diagnosa, pembayaran utang, olah pembelian, pemabayatn resep dan olah data produk.

\subsubsection{ACTIVITY DIAGRAM}

Berikut ini penulis akan menggambarkan beberapa activity diagram yang terdiri dari activity diagram pendaftaran, pemeriksaan, dan pembayaran resep. 
a. Activity diagram pendaftaran

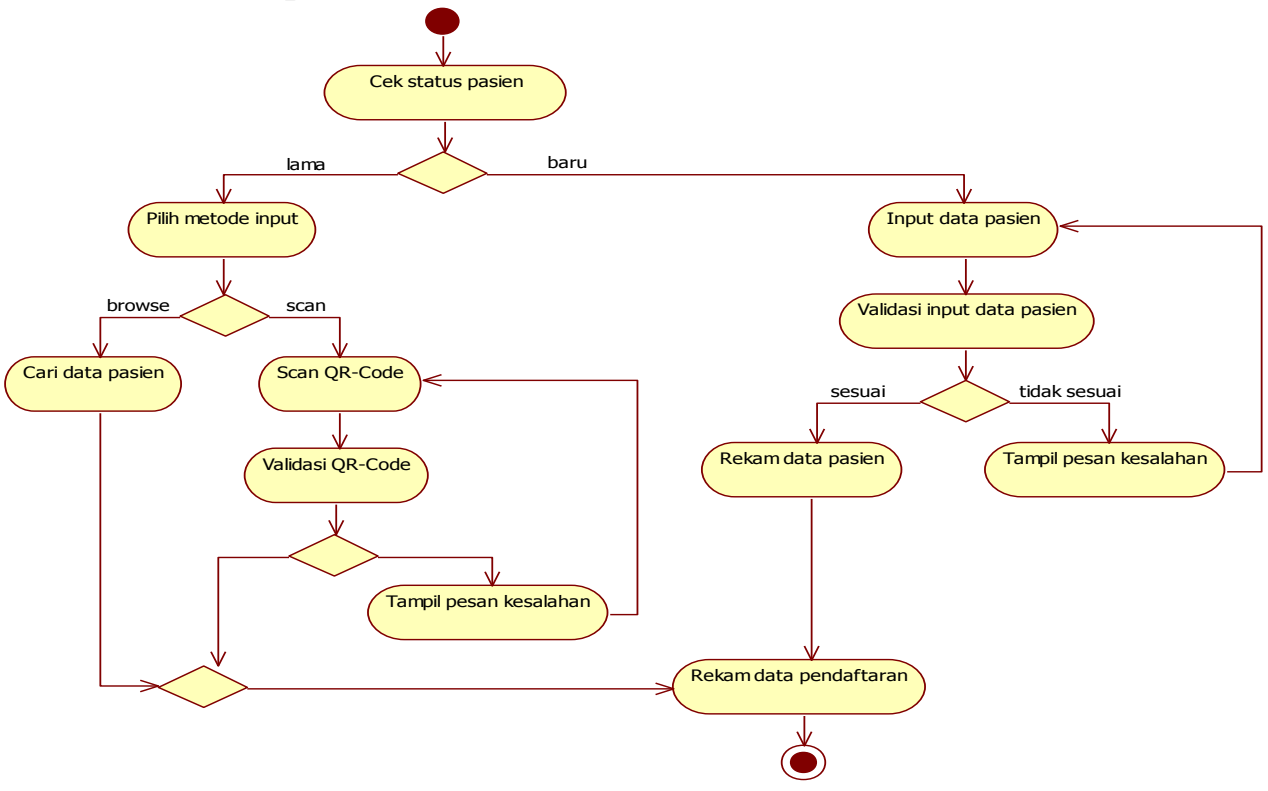

Gambar 4. Activity Diagram Pendaftaran

b. Activity diagram pemeriksaan

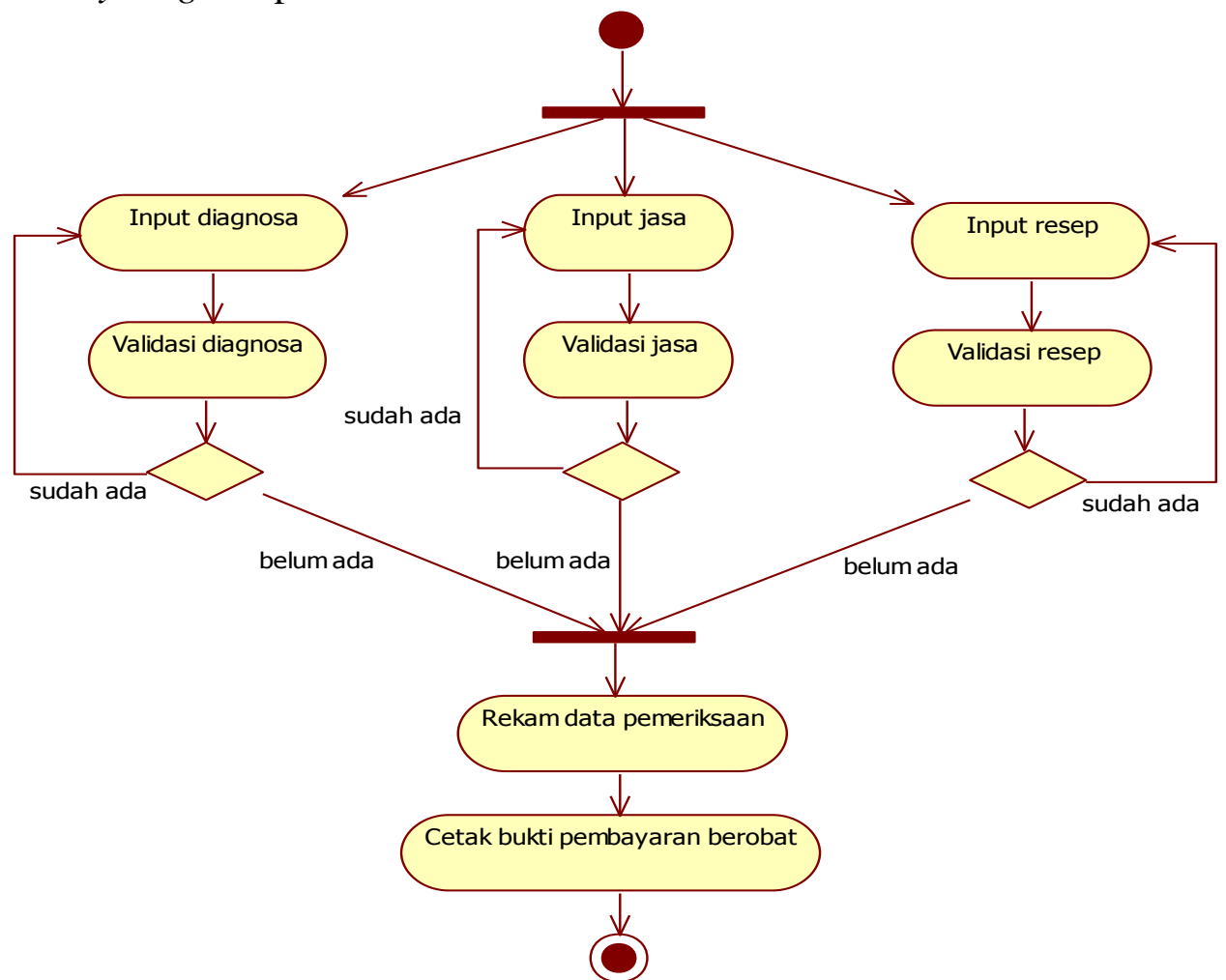

Gambar 5. Activity Diagram Pemeriksaan 
Activity diagram pembayaran resep

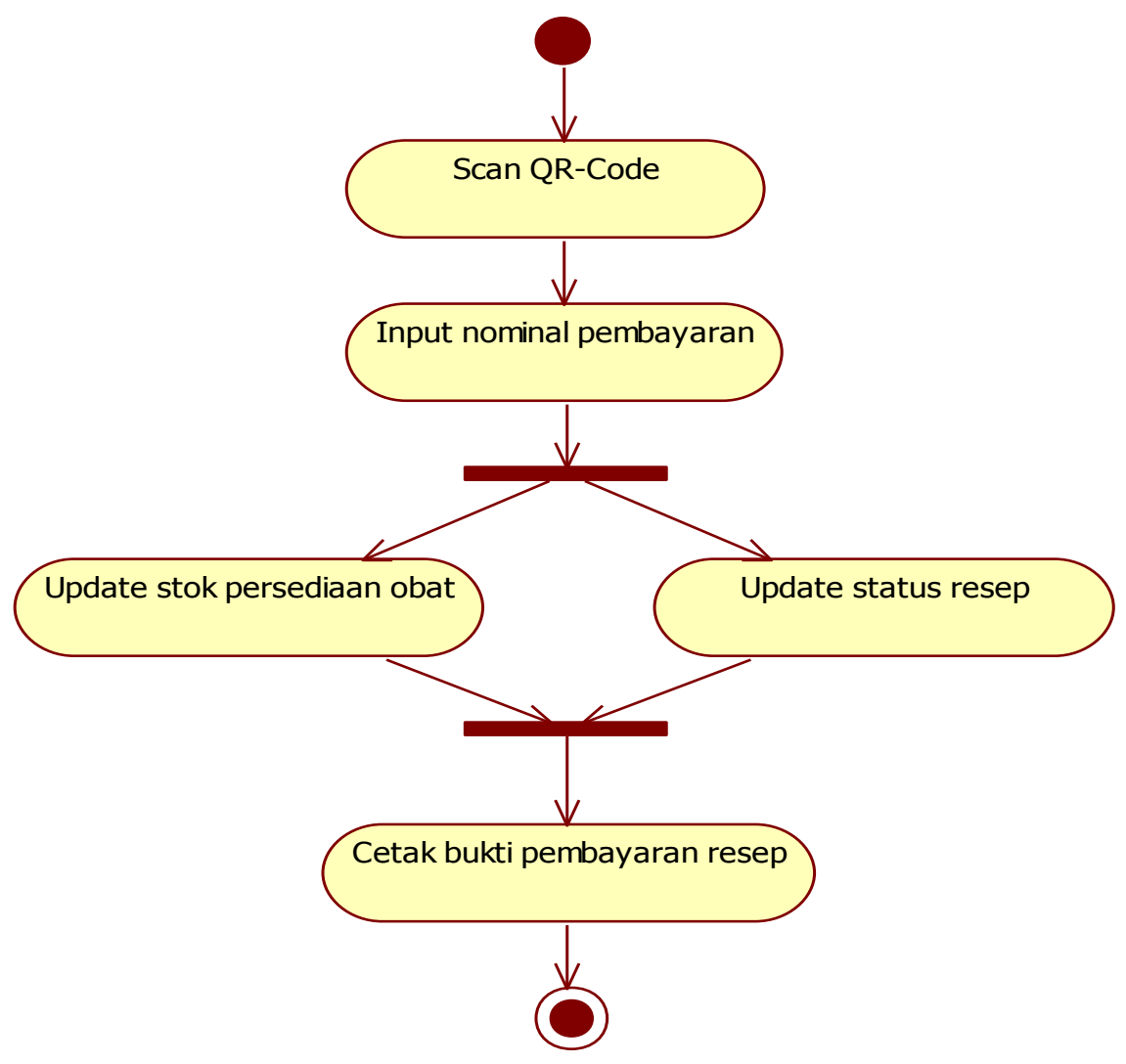

Gambar 6. Activity Diagram Pembayaran Resep

\subsection{PERANCANGAN SISTEM}

Perancangan sistem merupakan kegiatan membuat solusi sistem informasi sesuai dengan kebutuhan sistem. Model perancangan yang dibuat adalah Class diagram dan Perancangan Antarmuka.

\subsubsection{Class diagram}

Class diagram pada sistem yang baru akan penulis tunjukkan pada gambar 7 . 


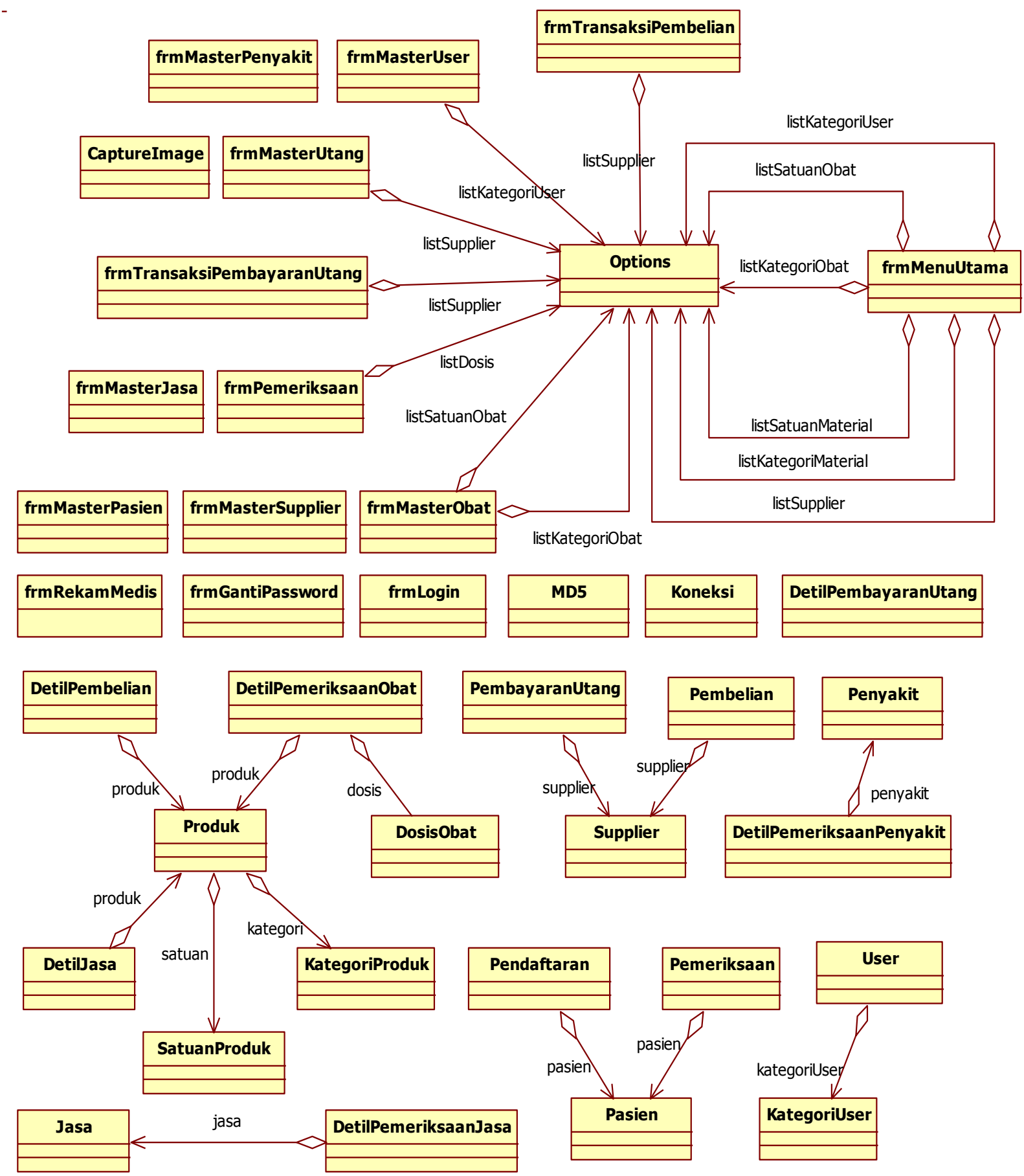

Gambar 7. Class Diagram

\subsubsection{PERANCANGAN ANTARMUKA}

Perancangan antarmuka merupakan alat untuk berkomunikasi antar pemakai dan sistem yang dibuat. Perancangan ini meliputi struktur menu, tata letak masukan, dan tata letak keluaran/output. 

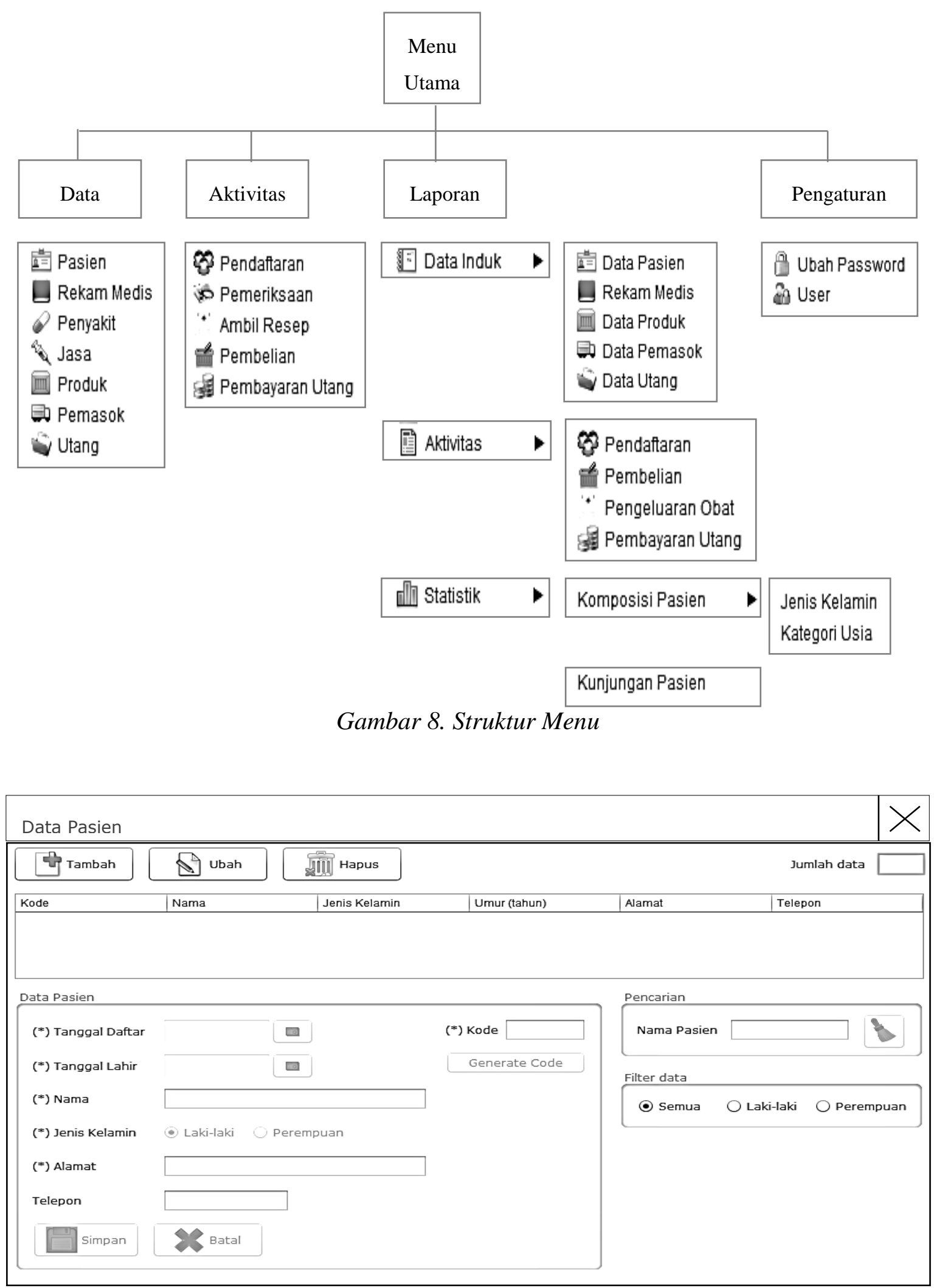

Gambar 9. Tata Letak Layar Form Data Pasien 


\begin{tabular}{|l|l|l|l|l|l|}
\hline \multicolumn{2}{|l|}{ Data Pendaftaran } & \\
\hline Nomor Urut & Kode Pasien & Nama Pasien & \\
\hline
\end{tabular}

Gambar 10. Tata letak layar form data pendaftaran

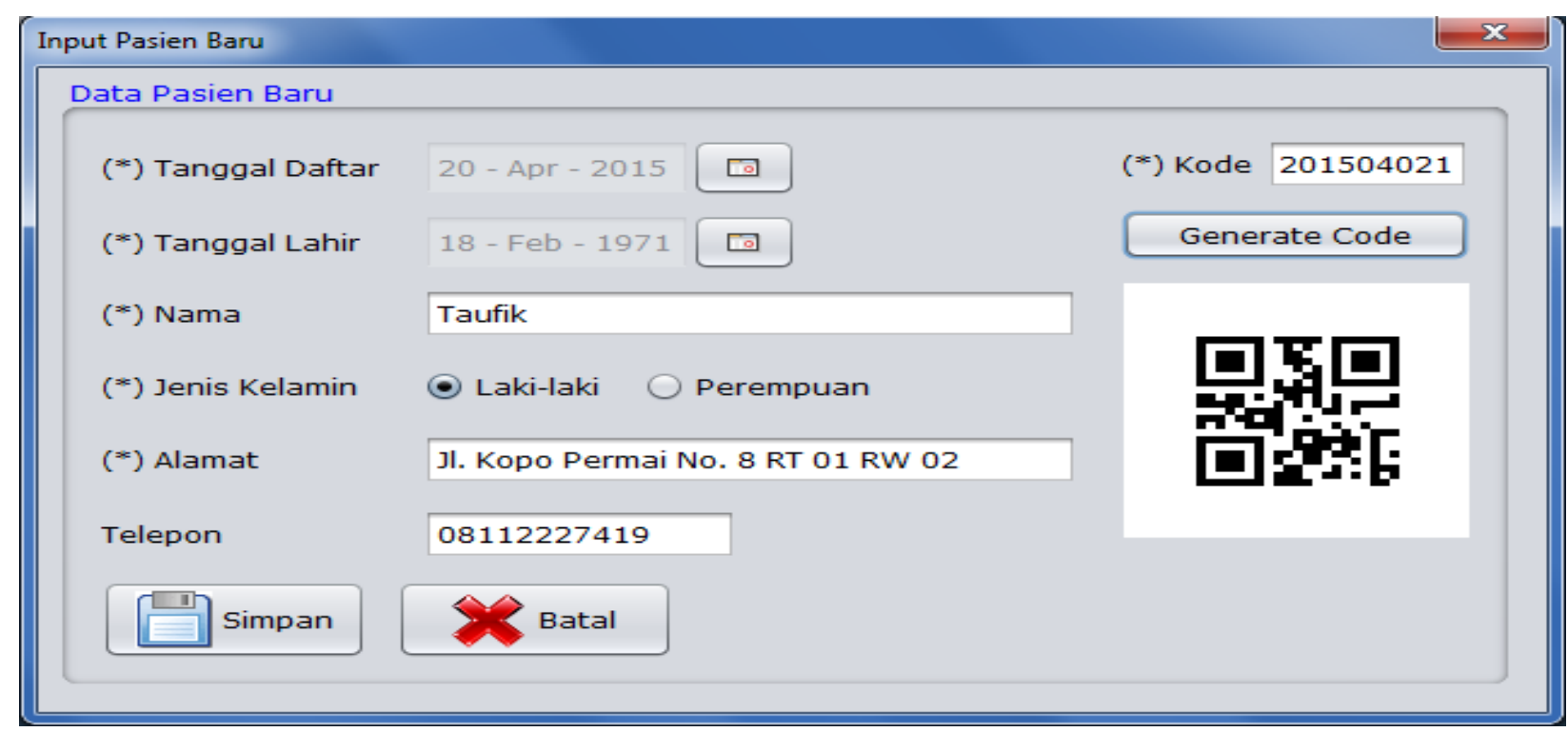

Gambar 11. Tata letak layar form input data pasien baru

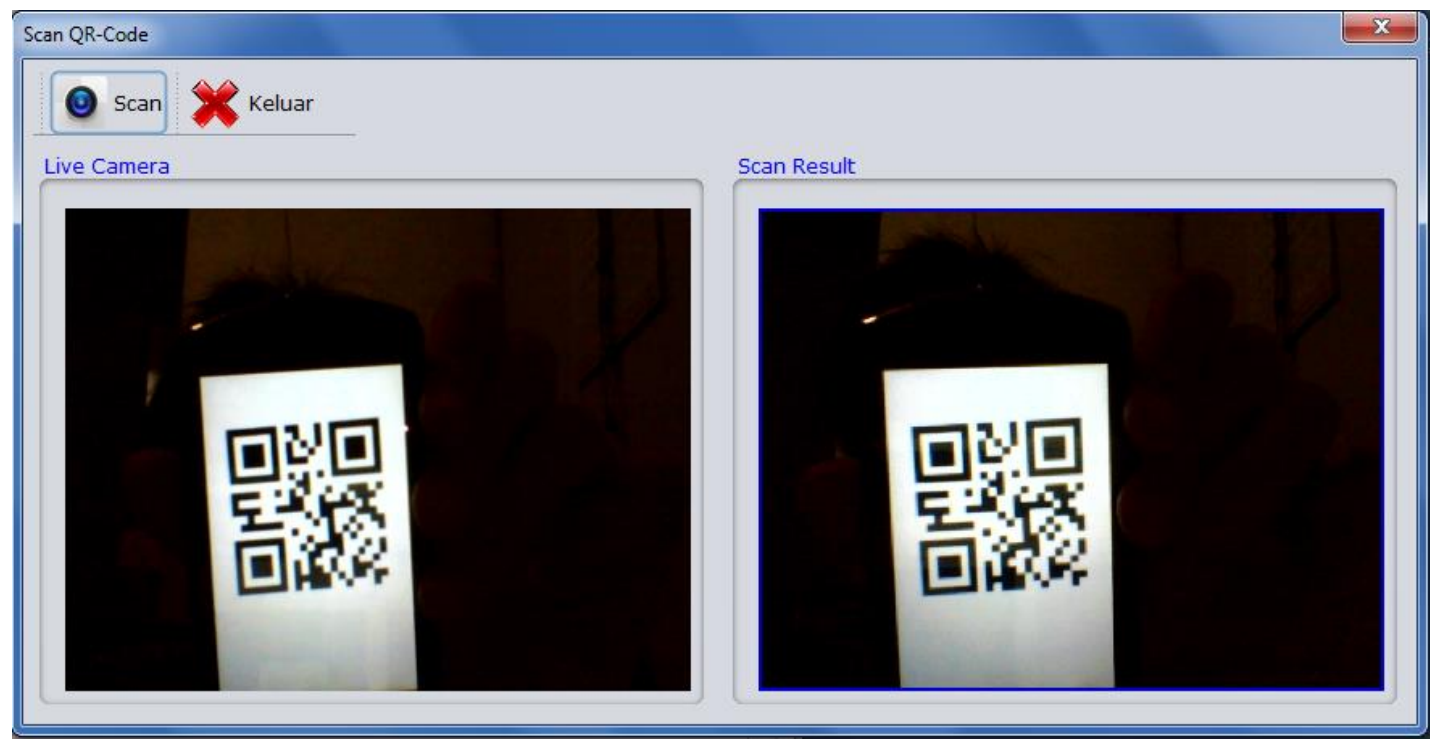

Gambar 12. Tata letak layar form scan QR-Code 


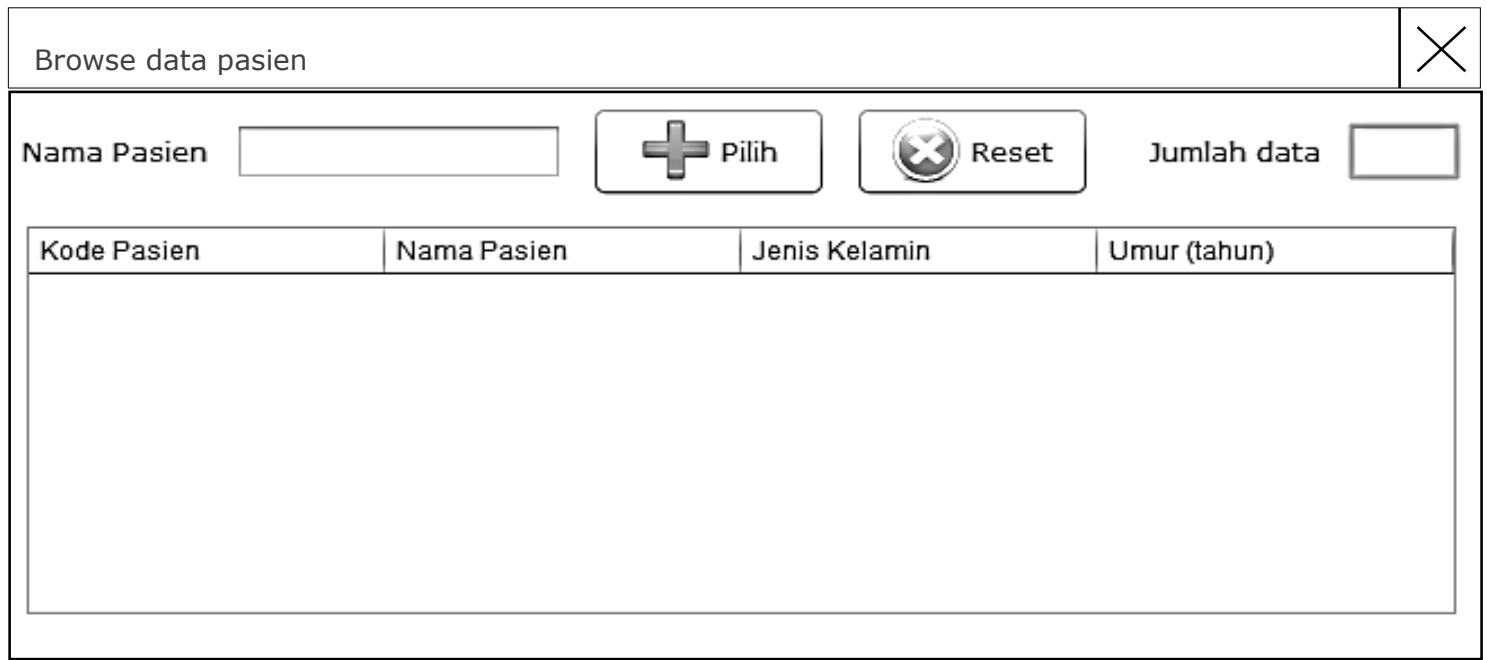

Gambar 13. Tata letak layar tambah data pendaftaran melalui browse data pasien

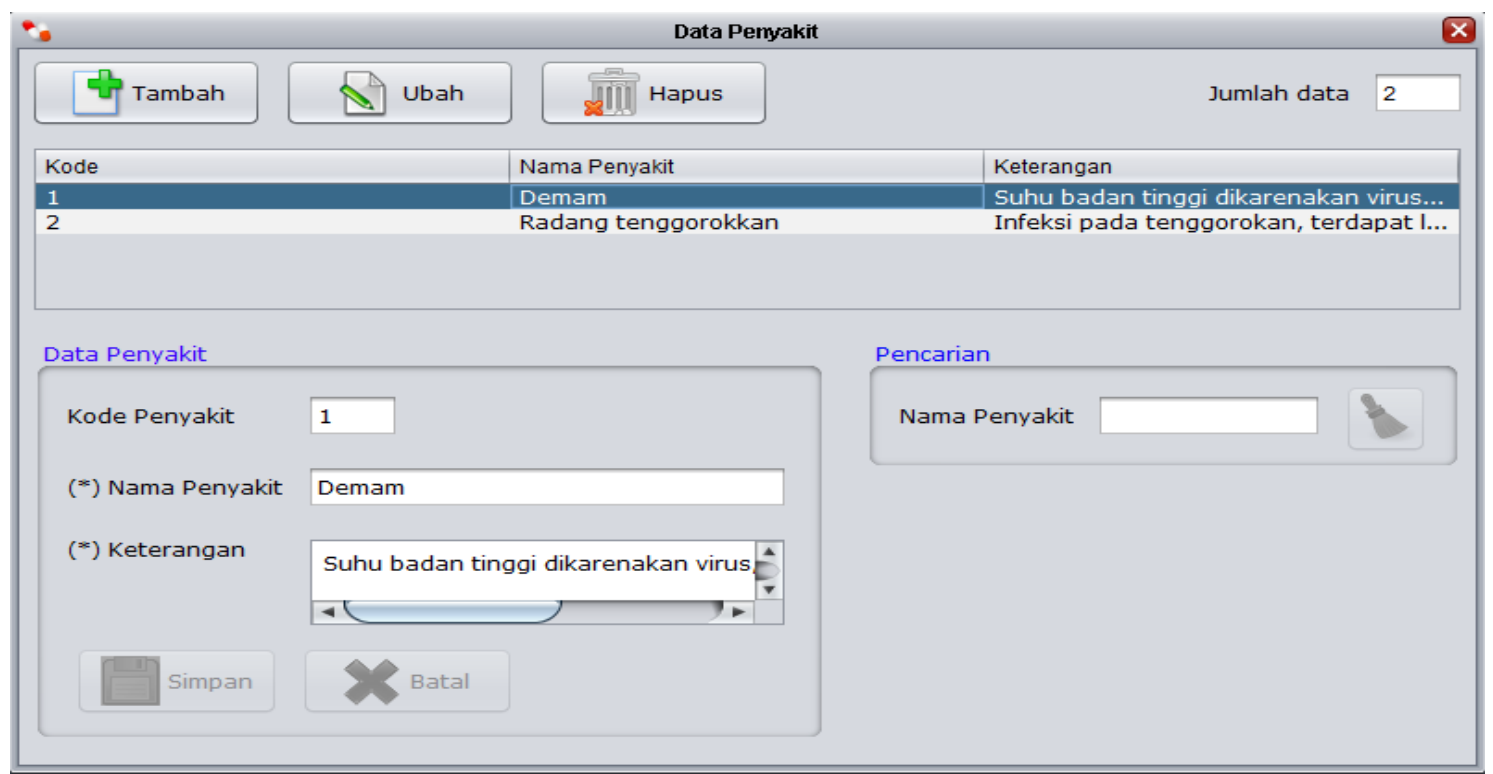

Gambar 14. Tata letak layar form data penyakit

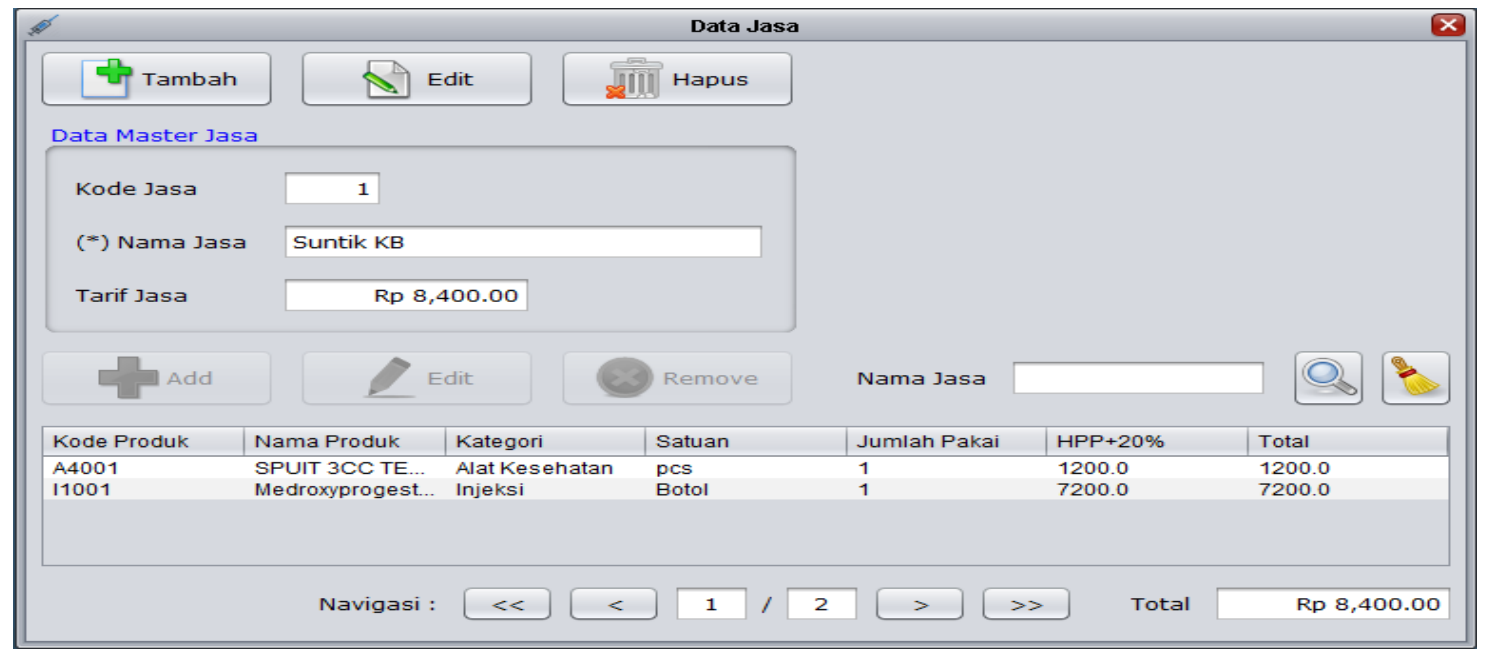

Gambar 15. Tata letak layar form data jasa 


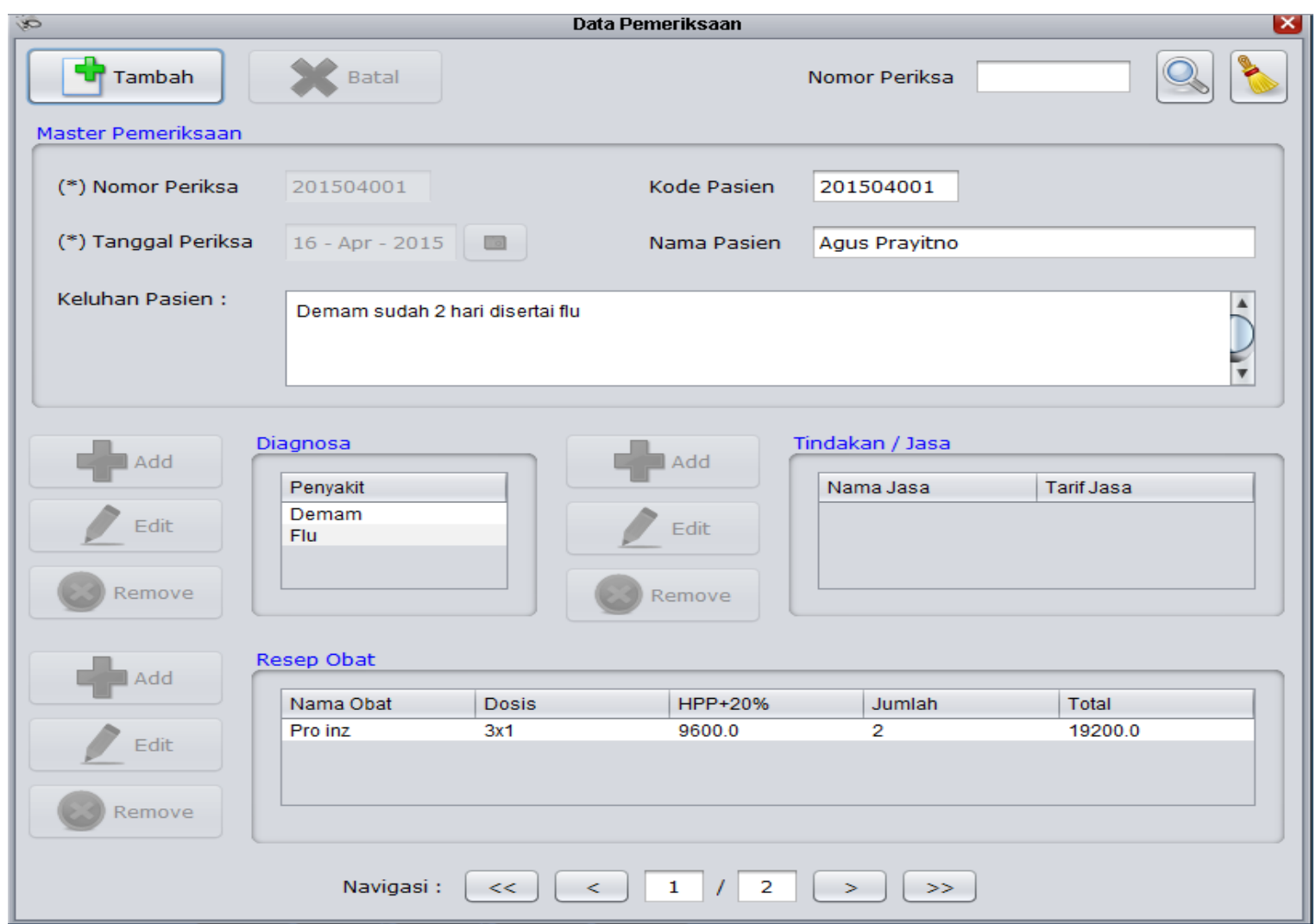

Gambar 16. Tata letak layar form data pemeriksaan

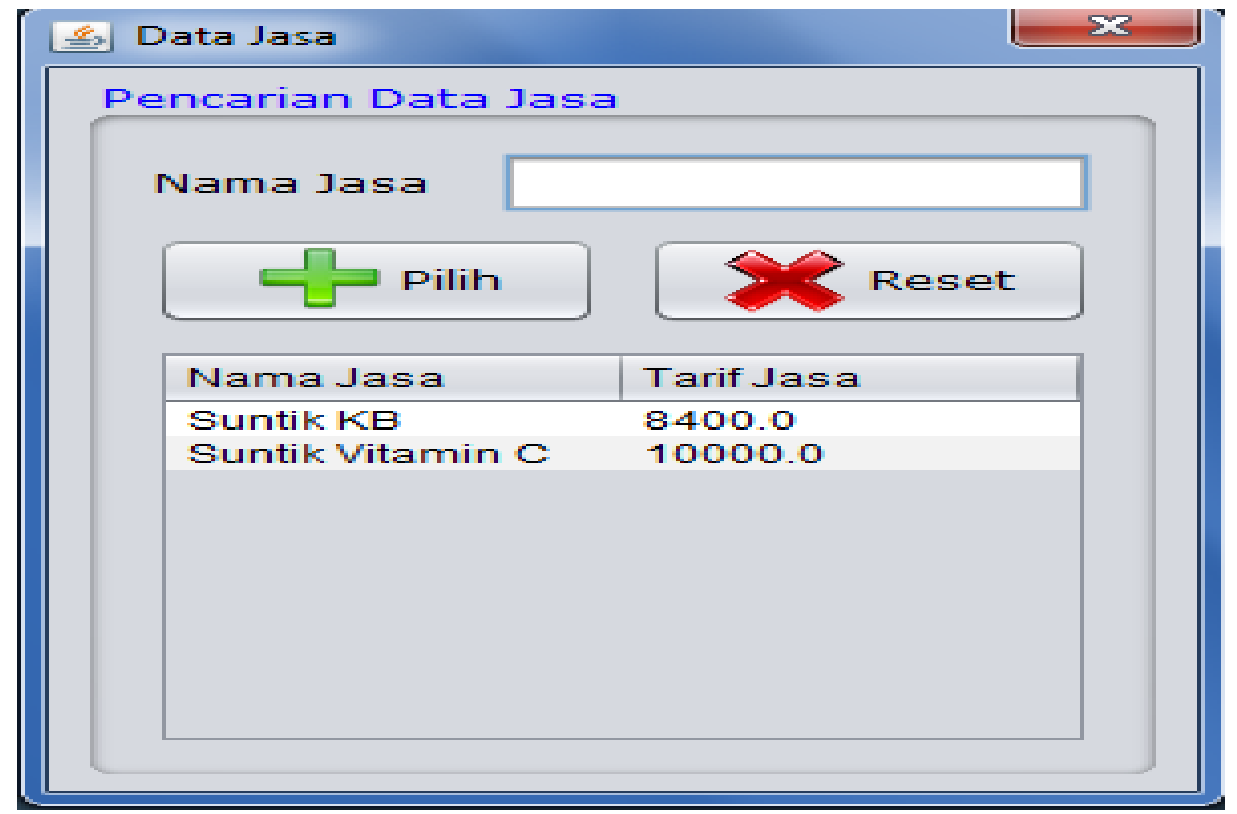

Gambar 17. Tata letak layar tambah atau ubah data jasa pada form pemeriksaan 


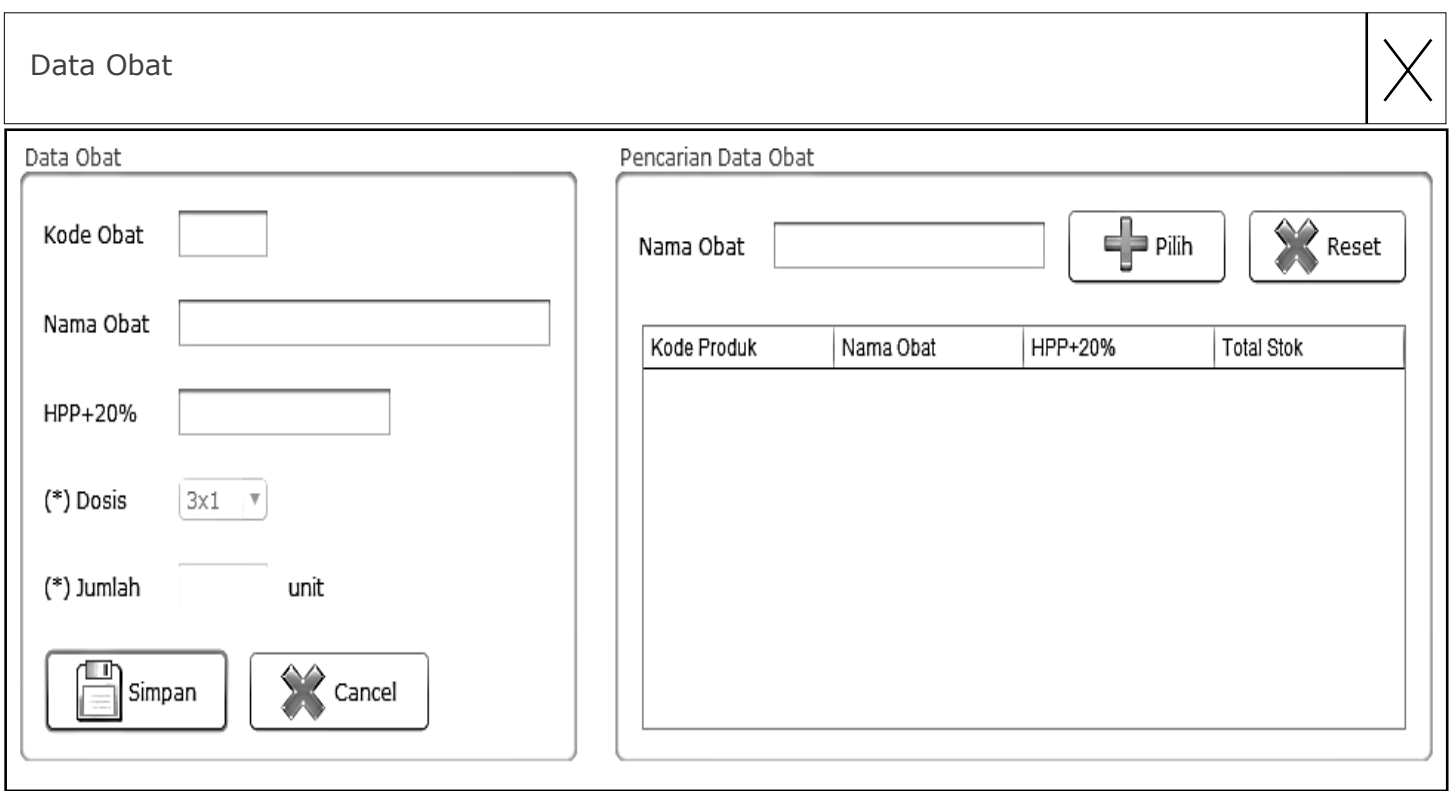

Gambar 18. Tata letak layar tambah atau ubah data obat

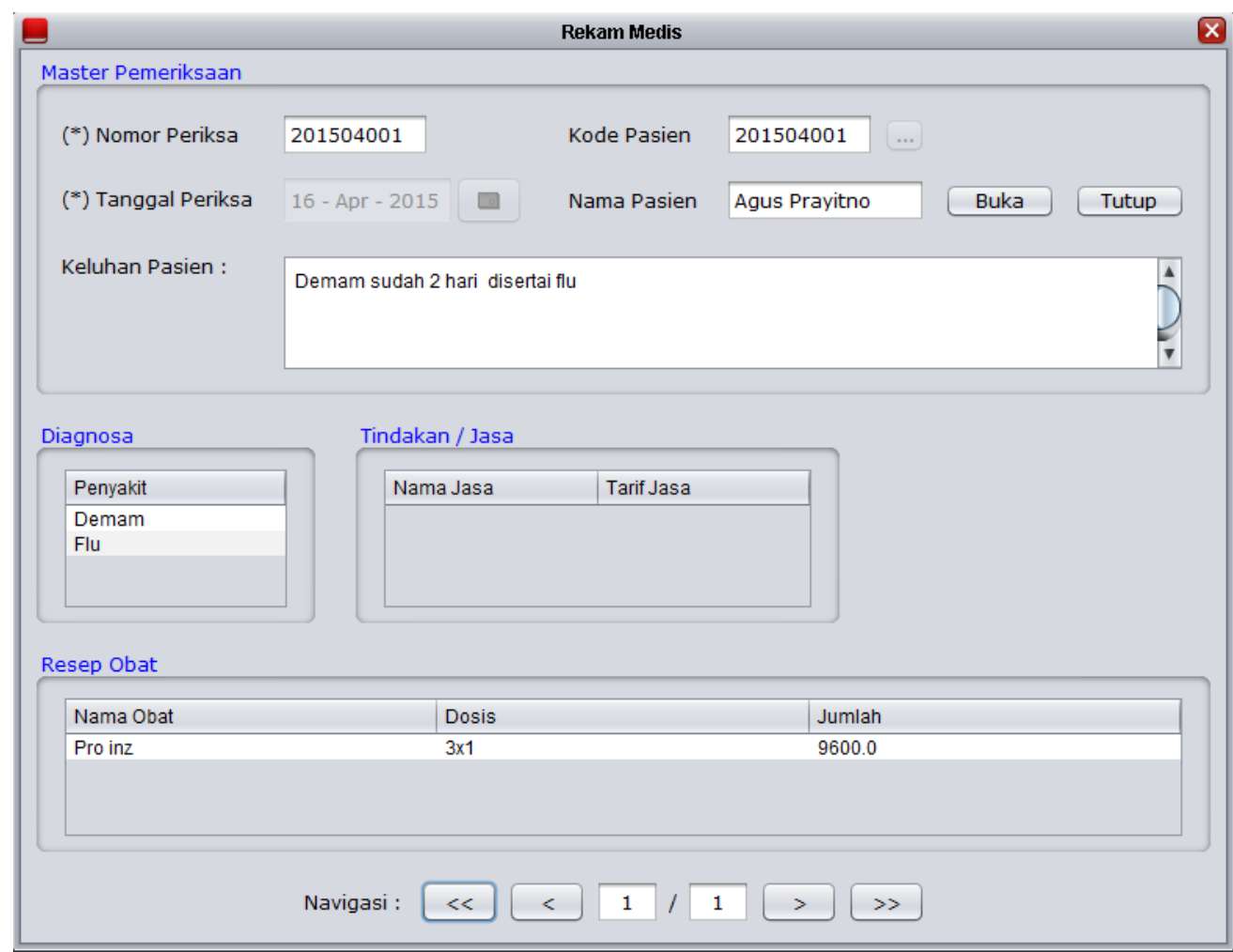

Gambar 19. Tata Letak Layar Form Rekam Medis 


\section{KESIMPULAN}

Kesimpulan untuk sistem informasi rawat jalan pada kliknik ST di Bandung, sebagai berikut :

a. Antrian pasien menjadi lebih teratur dan tertib karena diatur sistem ini.

b. Pencarian data pasien, riwayat kesehatan dan rekam medis pasien menjadi lebih cepat karena adanya fungsi pencarian pasien.

c. Terjadinya penghematan sumber daya berupa pengurangan penggunaan kertas untuk mencatat riwayat pemeriksaan pasien

d. Mengurangi kebutuhan akan tempat penyimpanan dokumen serta menghindari resiko kerusakan ataupun kehilangan dokumen yang disimpan

e. Konsistensi dan akurasi data selalu terjamin serta dapat diakses secara real time

f. Semua data penting yang tersimpan pada database terjamin keamanannya dan hanya dapat diakses oleh pihak-pihak yang diotorisasi

g. Proses pembuatan laporan menjadi tepat waktu, lebih cepat dan akurat serta memiliki format yang seragam sesuai dengan ketentuan.

\section{DAFTAR PUSTAKA}

[1]. Booch, Grady. 1998. Object-oriented analysis and design with applications 2nd edition. Addison Wesley.

[2]. Gaol, Chr. Jimmy L. 2008. Sistem Informasi Manajemen Pemahaman Dan Aplikasi. Jakarta: Grasindo.

[3]. Marsic, Ivan. 2012. Software Engineering. Rutgers University.

[4]. Munawar. 2005. Pemodelan Visual dengan UML. Yogyakarta: Graha Ilmu

[5]. Nugroho, Adi. 2005. Analisis dan Perancangan Sistem Informasi dengan Metodologi Berorientasi Objek. Bandung: Informatika.

[6]. Pressman, Roger. 2012. Software Engineering : A Practitioner's Approach, Seventh Edition. McGraw Hill.

[7]. Stephens, Rod. (2015), Beginning Software Engineering. John Wiley \& Sons, Inc.

[8]. Whitten, Jeffrey L, Bentley Lonnie D., 2007, Systems Analysis \& Design Method, , $7^{\text {th }}$, McGraw-Hill Irwin 